News and Views

\title{
Using Geophysical Survey to Investigate Underground Passages in and around Matky Boží Chapel
}

\author{
Pavlína Valováa ${ }^{\mathrm{a}, b^{*}}$, Věra Glisníkovác,d \\ ${ }^{a}$ GEODRILL Ltd., Bělohorská 2115/6, 62100 Brno; Czech Republic \\ ${ }^{b}$ Institute of Geological Sciences, Faculty of Science, Masaryk University, Kotlárská 2, 61137 Brno, Czech Republic \\ 'University of Technology, Faculty of Civil Engineering, Veveři 331/95, 60200 Brno, Czech Republic \\ ${ }^{d}$ VENTIMIGLIA Ltd., Ječná 1321/29a, 62100 Brno, Czech Republic
}

\section{ARTICLE INFO:}

\section{Article history:}

Received: 20 November 2011

Accepted: 20 December 2011

\section{Keywords:}

Brno - Veveří Castle

Matky Boží Chapel

geophysical survey

underground passages

Templar legend

\begin{abstract}
$A B S T R A C T$
According to legend, Veveří Castle and its surroundings, including Matky Boží Chapel, were associated with the Knights Templar. These legends tell us that knights hid Templar treasure in passages under the chapel. Geophysical survey was conducted in and around the chapel in order to ascertain the existence of these passages. Survey was conducted using dipole electromagnetic profiling (DEMP) and ground penetrating radar (GPR). The survey discovered some cavities under and around the chapel suggestive of the presence of crypts, or burials at the front of the chapel. There is an inhomogeneity indicative of the presence of linear underground structures to the south of the chapel. Further investigation of this anomaly would be required to prove or disprove the existence of underground passages.
\end{abstract}

\section{Introduction}

Veveři Castle sits on a rocky promontory surrounded by the Svratka River in a scenic landscape around Brno dam. Matky Boží Chapel (Figure 1) lies along an ancient tree alley near the castle. Like the castle, the Chapel is shrouded in legends and mysterious stories of Templar treasure, supposedly hidden here by Templar knights. Legends describe underground passages, connecting Matky Boží Chapel to Veveří Castle, in which the Templar treasure was supposedly hidden (Čižmář, Rácek 2011). Geophysical examination was undertaken in order to determine what might lie hidden under the Chapel floors and within underground passages mentioned in several historical documents.

\section{Methodology}

Geophysical survey was conducted within and around the chapel. The survey area and location of geophysical

"Corresponding author. E-mail: pavlina@geodrill.cz profiles are indicated on Figure 2. Two geophysical methods were used; ground penetrating radar (GPR) and dipole electromagnetic profiling (DEMP) (Tomešek et al. 2011). The application of geophysical methods was given with regard to the environmental conditions, which was near the chapel e.g. walls and in the interior e.g. equipment, but especially with regard to aim of the survey, which was reached underground structures under chapel itself and its surroundings. Because the chapel is a protected monument it was necessary to use non-destructive contactless methods. For reaching the cavities and underground structures it is best to use of GPR method. In this case was this method accompanied by DEMP. The main aim of DEMP was mapping of a distribution of conductivity in front of the chapel.

\subsection{GPR}

GPR is based on the transmission and subsequent reception of electromagnetic impulses, reflected from various subsurface layers, which creates a visual representation of the target area. The signal quality and reflection time depend on the depth of reflecting layers, the permittivity of the environment, and the distance between transmitting 


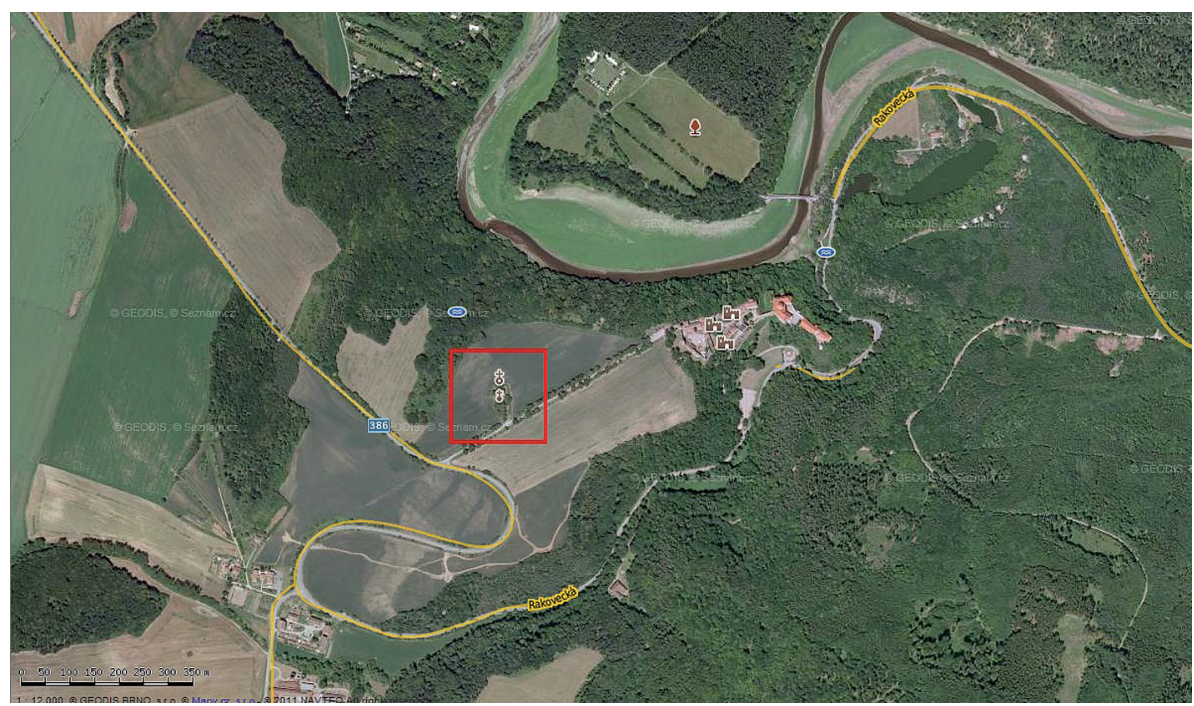

Figure 1. Overview of the research area (www.mapy.cz)

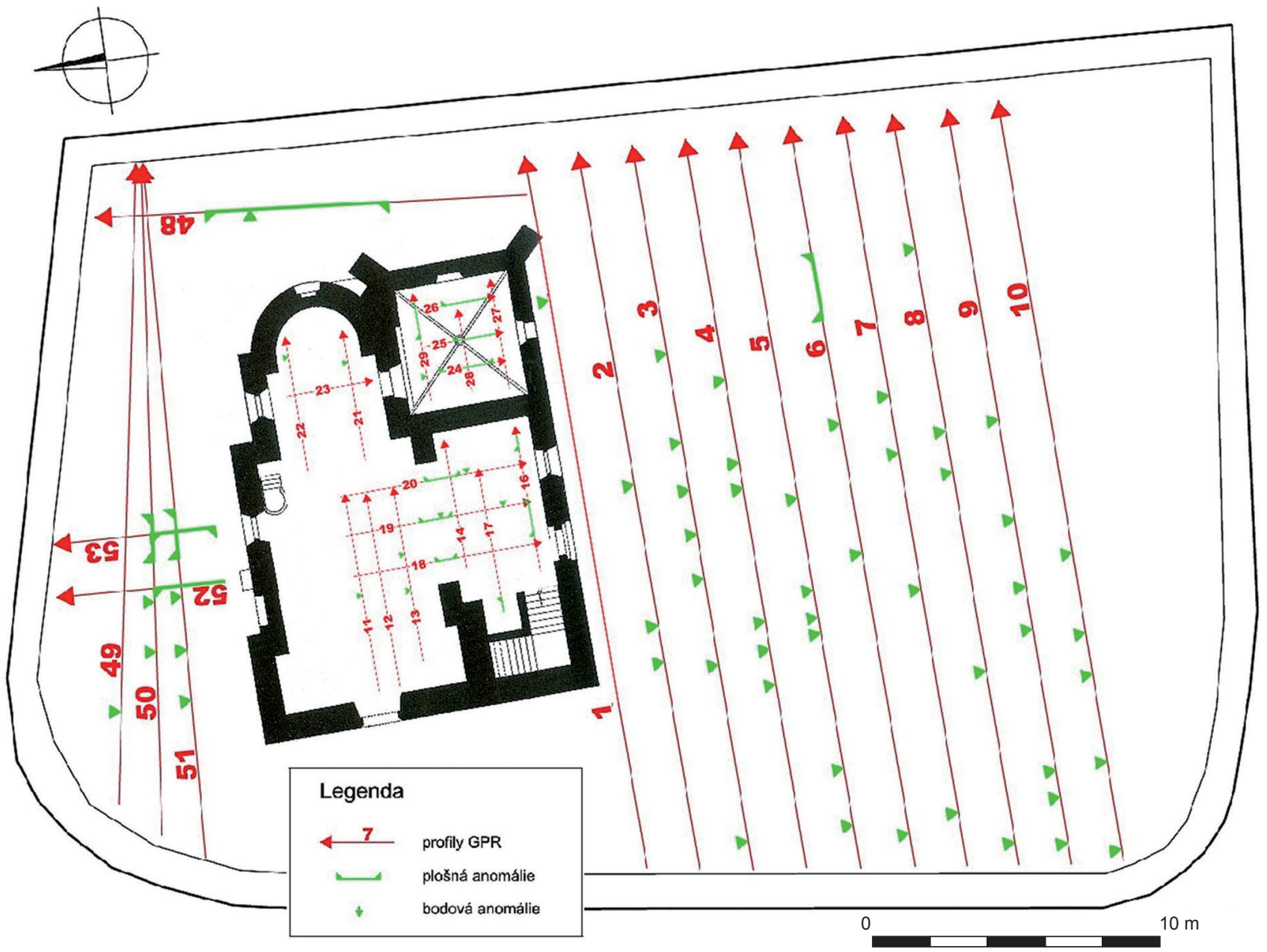

and receiving antennas. The depth range depends on signal frequency and permittivity. GPR detects reflective subsurface soil or rock layers and indicates the presence of possible irregularities, such as cavities, inhomogeneous zones, underground construction, modern utilities, etc. The output indicates time or depth sections (radar sections) highlighting inhomogeneities of interest. GPR was carried out with a Swedish digital georadar. A laptop was used as the control unit. Researchers selected a system of antennas suited to $250 \mathrm{MHz}$ in order to optimise penetration depth in relation to known anomalies. For survey within the chapel, frequency was increased to $500 \mathrm{MHz}$ to allow a detailed evaluation of the surface layer. Measurements were recorded in a computer, which also functioned as a control centre of 
Figure 3. GPR measurment inside the chapel (photo K. Turek).

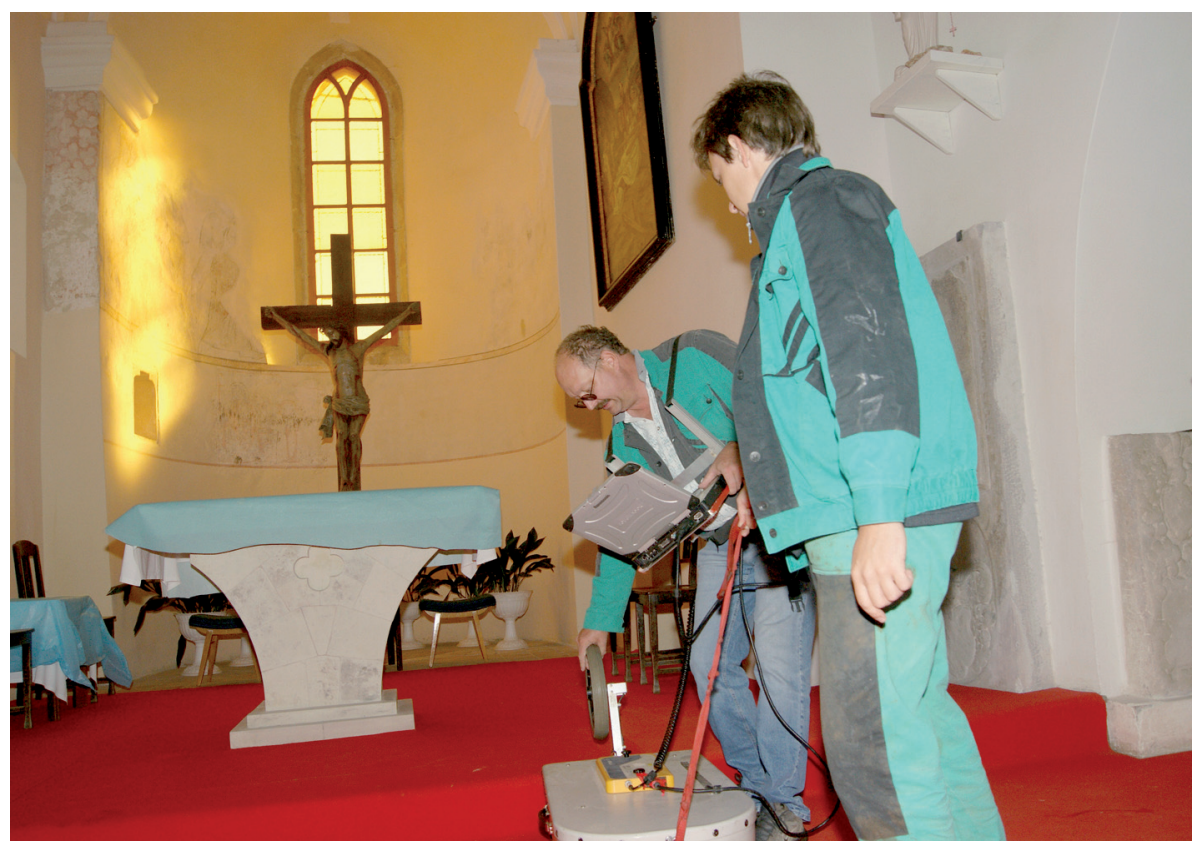

located about $400 \mathrm{~m}$ southwest of the Veveři Castle, along the road leading from the main access road to the castle's upper gate. The chapel, also known as "Matky Boží Veverské", dates to the $12^{\text {th }}$ century, and is first mentioned in written

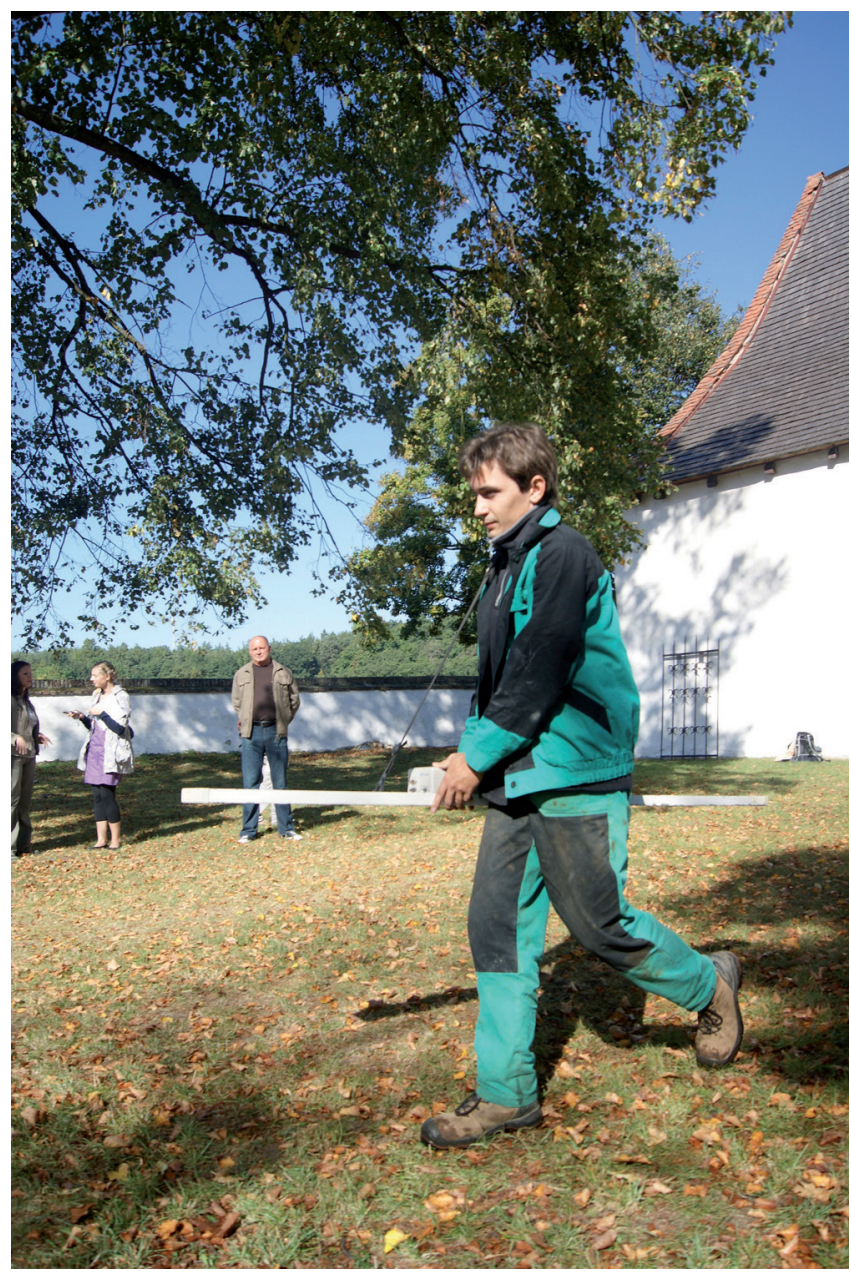

Figure 4. DEMP measurement in front of the chapel (photo K. Turek).
The subject of the survey was the two-nave Matky Boži

Chapel and the area immediately around it. The chapel is a Swedish commercial software package. Data was digitally processed using a German commercial software package. The data was organized into radar sections of measured cross sections, in the form of time and depth sections.

GPR sections were run parallel with the south side of the chapel at $2 \mathrm{~m}$ intervals. This was complemented by a section on the eastern side, and several sections along the north side. Measurements were conducted at $250 \mathrm{MHz}$. In the chapel (Figure 3) measurement was restricted by the structure and furnishing, but was conducted in perpendicular crosssections at $250 \mathrm{MHz}$. In order to provide more specific and complete picture, the same interior cross-sections were also measured at $500 \mathrm{MHz}$.

\subsection{DEMP}

DEMP was conducted using the USA multifrequency conductometer, which works with variable frequencies and a fixed $2 \mathrm{~m}$ distance between the transmitting and the receiving dipoles. Measurements were taken at $6075 \mathrm{~Hz}, 13025 \mathrm{~Hz}$, $27025 \mathrm{~Hz}$ and $47025 \mathrm{~Hz}$. Depth, largely determined by frequency and dipole spacing, reached in these conditions the effective depth range 3-4 m. Other factors affecting penetration include soil conductivity, and the character of the anomalous zone, such as size, placement, etc.

DEMP was only used outside the chapel (Figure 4), in the same area as the GPR survey, on N-S axis at $2 \mathrm{~m}$ intervals. DEMP was used around the chapel to obtain data about the location and extent of potential cavities with lower conductivity.

\section{History of Matky Boží Chapel}




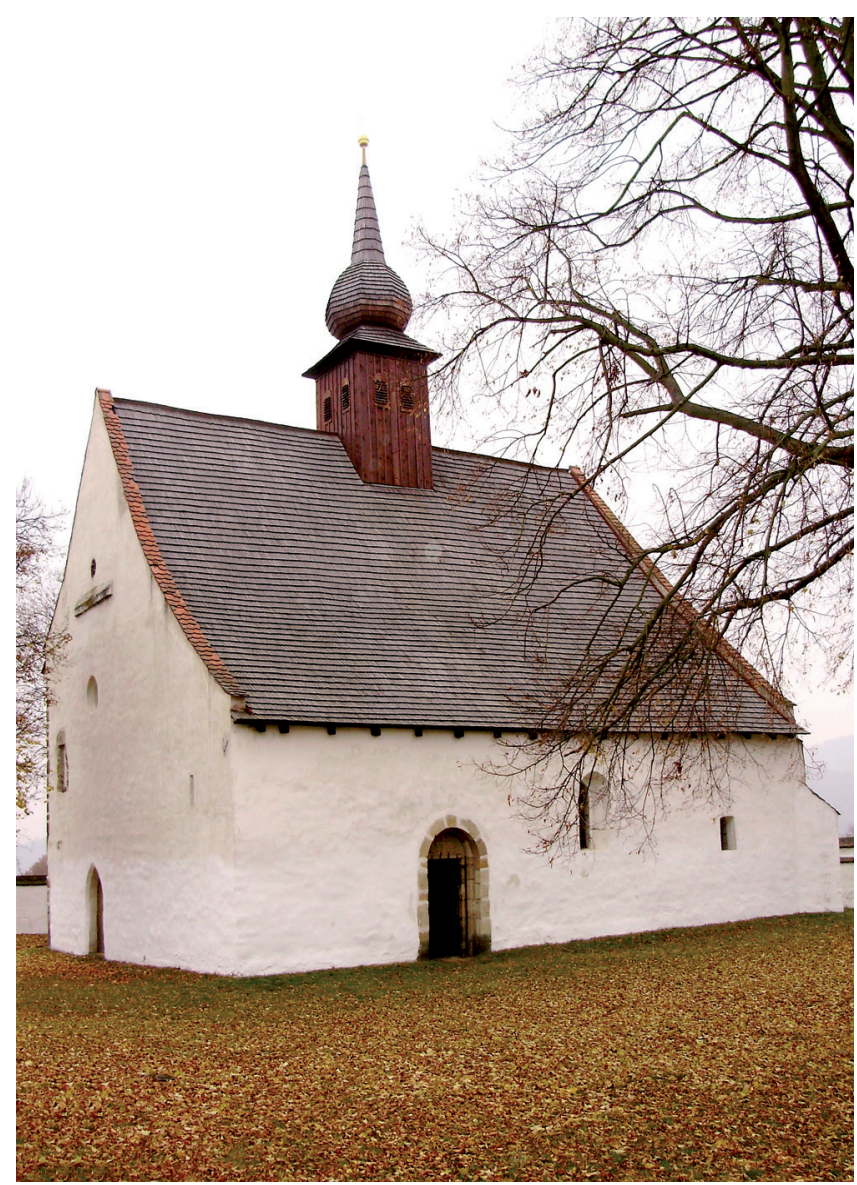

Figure 5. View of the snow-white Matky Boží Chapel (photo P. Valová).

records in 1240 . In the vicinity of the chapel there was a medieval village which disappeared during the later Hussite wars (Flodrová 2002).

The chapel (Figure 5) currently has a shingled roof and turret with two bells. Originally Romanesque, it was later partly rebuilt in Gothic style. Allegedly, prior to the Thirty Year War there was a chapel tower, but it was demolished by the Swedes after an unsuccessful attempt to capture Veveři Castle. The original Romanesque chapel, with apse and main nave, was built in the $12^{\text {th }}$ century. Remaining Romanesque elements include windows, vaults, tiles and the pulpit. The Romanesque south entrance portal is decorated with a relief of a Greek cross, moon, sun and two lions, and leads into a Gothic lateral nave. The sacristy dates to the mid $-15^{\text {th }}$ century with later minor Baroque adjustments. The western entrance to the Romanesque main nave is Gothic with remains of Gothic murals. On the east gable wall is an obviously lateGothic relief of a human face (Sommer 2003).

The area around the chapel served as a cemetery for neighbouring villages up to the early $19^{\text {th }}$ century. During World War II the chapel was used as a stable, and mortar shelling inflicted extensive damage to the roof. After extensive repair the chapel is now used for weddings and occasional services. (Čižmár̆, Rácek 2011).

\section{Research Findings}

\subsection{GPR findings}

Numerous inhomogeneities, largely between 0.4 to $0.6 \mathrm{~m}$ deep, are evident on GPR sections obtained from the south front of the chapel. A higher frequency of inhomogeneities was observed west of the chapel entrance. These are presumed to be tombstones and remains of earlier burials which were covered later by backfill. Sections PF2 to PF10 (Figure 6) show a significant inhomogeneity at $3.5 \mathrm{~m}$, increasing to $4.8 \mathrm{~m}$ towards the chapel. The inhomogeneity occasionally manifested at the maximum GPR depth range and it is not possible to exclude the existence of linear underground structures. Verification is recommended. Evidence of cavities, likely crypts, was detected along the north wall. Perpendicular sections confirmed this finding. These cavities are not found further than $3 \mathrm{~m}$ north of the wall.

GPR sections from within the northern section of the chapel are relatively homogeneous around the pews and

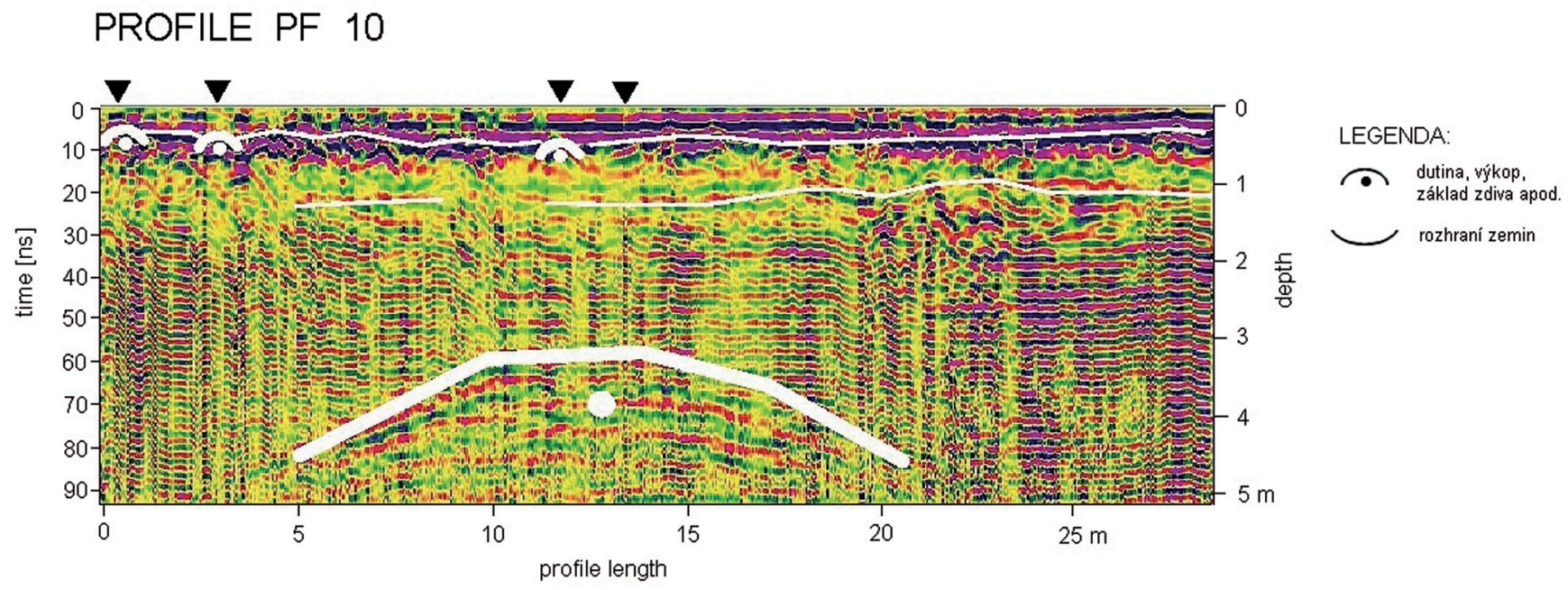

Figure 6. Radarogram example, from cross-sections located south of the chapel. 
altar. Pronounced, but shallow, inhomogeneities appear at the entrance by the staircase and in the sacristy. Sections PF18 to PF20 contain flat shallow anomalies likely related to the various phases of construction, and are probably remnants of the foundation wall that was moved during later expansion of the ground plan. Special attention was paid to a hollow-sounding space in the sacristy found in section PF29. It is thought that this is a relatively shallow space without vaulting. Sections PF24 to PF26 show shallow layers moving southward, from $0.5 \mathrm{~m}$ to about $1 \mathrm{~m}$ deep. A distinct anomaly at $2 \mathrm{~m}$ was detected in section PF16 at the right of the chapel entrance. It is impossible to reliably interpret and should be verified by excavation or probe.

\subsection{DEMP findings}

Data obtained by DEMP were incorporated into a map of apparent conductivities $\sigma_{z d}$ at 13,025 Hz. The survey found that conductivity increase to the southwest, likely as a result of the increasing thickness of the bedrock layer in this direction. The character of this transition is relatively gradual and no local anomalies, such as lines of reduced conductivity indicative of passages or other anthropogenic cavities, were apparent. A significant anomaly along the western side of the chapel was caused by a metal grid.

\section{Discussion}

The purpose of the geophysical survey was to assess the existence of subsurface inhomogeneities, cavities or passages in and around Matky Boží Chapel. A combination of two geophysical survey methods, DEMP and GPR, at $250 \mathrm{MHz}$ and $500 \mathrm{MHz}$, was used for this purpose.

The evaluation of survey data supports the following conclusions. DEMP detected increases conductivity up to $48 \mathrm{mS} / \mathrm{m}$ to the southwest, caused by the increasing thickness of bedrock. No isometric anomaly, with reduced conductivity indicative of a possible passage, was located.

A large number of relatively shallow anomalies were detected with GPR south of the chapel's front entrance. Concentrated in the southwestern portion of the survey area these anomalies probably relate to earlier burials covered with soil over time. On cross sections PF2 to PF10 a linear inhomogeneity is apparent at $3.5 \mathrm{~m}$, increasing to $4.8 \mathrm{~m}$ towards the chapel. In the first case the aerial echo from the chapel wall was considered. But it is not probable, because it is not detected on the cross section PF1, which is located closest to the wall of the chapel and due to the slope of the shoulders of the anomaly on PF2 to PF10 and its run to the shallower depth in the direction from the chapel. Therefore other justifications for this anomaly must have been taken in account. It is not possible to exclude the existence of a linear underground structure, given that measurements taken are at the bottom of the depth range of the GPR method used. It would be useful to verify this anomaly through further geophysical survey or probe. Cavities representing possible burial crypts were detected north of the chapel and should be verified by probe and microcamera. Within the chapel the survey focused on the hollow sounding space in the sacristy, where a rather shallow cavity without vaulting was detected. This cavity is likely not a passage, but rather an isolated cavity of unknown function. A distinct anomaly was found to the eastwards to the chapel entrance. In both cases it would be appropriate to verify these anomalies by probe.

\section{Conclusion}

This research used a combination of DEMP and GPR for geophysical survey. Anomalies found in front of the chapel are probably earlier burials. Indications of underground passages, probably crypts, were identified on the north side of the chapel. In the area of the sacristy a shallow underground space without signs of vaulting was detected, but is not likely to be an underground passage. Geophysical survey has not uncovered indications of underground passages within the chapel or its immediate surroundings.

\section{Acknowledgement}

This article was prepared within the scope of Research Project VZ MSM 0021630519.

\section{References}

ČIŽMÁŘ, Z., RÁCEK, J. 2011: Průvodce templářskou legendou hradu Veverí. Brno.

FLODROVÁ, M. 2002: Veverská kaple Matky Boži aneb kostelik Nanebevzetí P. Marie na Veverí. Brno.

SOMMER, J. 2003: Veveři, hrad: architektonické detaily v bývalé kapli a v britové věži. MONUDET-3, Praha.

TOMEŠEK, H., KUBÍČEK, P., VALOVÁ, P. 2011: Geofyzikální průzkum v prostoru kaple Matky Boží u hradu Veveř́i. GEODRILL s.r.o. MS. Final report, nr. 824/1. Deposited: Archive of the Final Reports, GEODRILL s.r.o., Brno. 
